\title{
Vessel wall MRI of an inflamed aneurysm with atherosclerosis in a patient with ischemic stroke
}

Figure High-resolution vessel wall MRI of a symptomatic, inflamed intracranial aneurysm with adjacent atherosclerosis
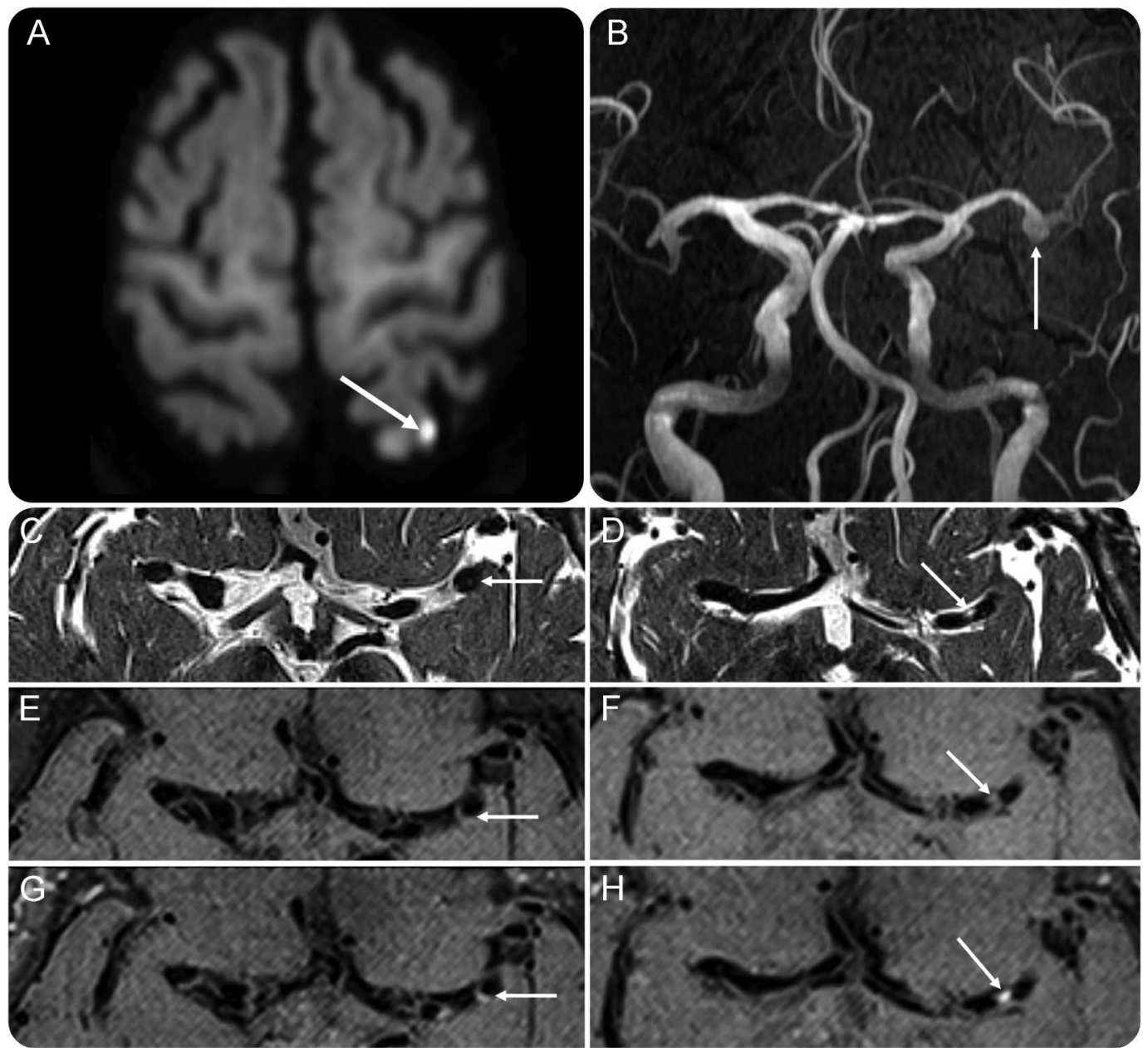

(A) Diffusion-weighted MRI with left parietal infarct. (B) Left middle cerebral artery bifurcation aneurysm. (C) T2 flow void of the aneurysm. (E) T1 precontrast aneurysm wall, which enhances after contrast administration (G). (D) T2 with hyperintense fibrous cap of an adjacent atherosclerotic plaque. (A) T1 precontrast with atherosclerotic fibrous cap, which also enhances after contrast $(\mathrm{H})$.

A 69-year-old woman presented with right leg weakness and ataxia. CT angiogram revealed a 6-mm left middle cerebral artery (MCA) aneurysm. Intracranial vessel wall MRI (IVWM) (figure) showed ischemic strokes in the left MCA region, inflammatory changes in the aneurysmal wall, and adjacent atherosclerosis. IVWM is a highresolution black-blood MRI technique that allows visualization of the arterial vessel wall. Postcontrast enhancement of unruptured aneurysms is associated with instability, ${ }^{1}$ and atherosclerotic plaque enhancement is associated with ischemic stroke. ${ }^{2}$ This report of a patient with ischemic stroke shows the association of a symptomatic inflamed aneurysm with atherosclerotic plaque on IVWM.

Adam de Havenon, MD, Min Park, MD, Scott McNally, MD, PhD

From the University of Utah, Salt Lake City. 
Author contributions: Adam de Havenon: drafting/revising the manuscript, study concept or design, analysis or interpretation of data, accepts responsibility for conduct of research and final approval. Min Park: drafting/revising the manuscript, accepts responsibility for conduct of research and final approval. Scott McNally: drafting/revising the manuscript, study concept or design, analysis or interpretation of data, accepts responsibility for conduct of research and final approval, acquisition of data.

Study funding: No targeted funding reported.

Disclosure: The authors report no disclosures relevant to the manuscript. Go to Neurology.org for full disclosures.

Correspondence to Dr. de Havenon: adam.dehavenon@hsc.utah.edu

1. Edjlali M, Gentric J-C, Régent-Rodriguez C, et al. Does aneurysmal wall enhancement on vessel wall MRI help to distinguish stable from unstable intracranial aneurysms? Stroke 2014;45:3704-3706.

2. Skarpathiotakis M, Mandell DM, Swartz RH, Tomlinson G, Mikulis DJ. Intracranial atherosclerotic plaque enhancement in patients with ischemic stroke. Am J Neuroradiol 2013;34:299-304.

\section{Save These Dates for AAN CME Opportunities!}

Mark these dates on your calendar for exciting continuing education conferences by the American Academy of Neurology. Learn more at AAN.com/conferences.

\section{Fall Conference}

- October 14-16, 2016, Las Vegas, NV, at the Cosmopolitan of Las Vegas

Breakthroughs in Neurology

- January 13-16, 2017, Phoenix, AZ, at the Sheraton Grand at Wild Horse Pass

AAN Annual Meeting

- April 22-28, 2017, Boston, MA, at the Boston Convention Center

\section{AAN is Committed to Making a Difference: 2017 AAN Research Program}

The AAN's ambitious 2017 AAN Research Program offers 20 opportunities, including two new AAN-funded awards: $\$ 450,000$ for junior investigators interested in clinical, translational, or basic research; and $\$ 130,000$ for basic science research training.

Two additional non disease-specific scholarships are available in clinical and practice-based research; additional targeted funding opportunities include support for research in ALS, Alzheimer disease, ataxia, epilepsy, multiple sclerosis, muscular dystrophy, Parkinson disease, stroke, and Tourette syndrome.

Visit AAN.com/view/ResearchProgram to learn more and apply by the October 1, 2016, deadline!

The AAN is committed to making a profound difference in the lives of researchers by promoting neurology and neuroscience research and training, which in turn will make a difference in the lives of patients with brain disease. 


\section{Neurology}

\section{Vessel wall MRI of an inflamed aneurysm with atherosclerosis in a patient with ischemic stroke}

Adam de Havenon, Min Park and Scott McNally

Neurology 2016;87;741-742

DOI 10.1212/WNL.0000000000002990

\section{This information is current as of August 15, 2016}

\section{Updated Information \& Services}

References

Subspecialty Collections

Permissions \& Licensing

Reprints including high resolution figures, can be found at: http://n.neurology.org/content/87/7/741.full

This article cites 2 articles, 2 of which you can access for free at: http://n.neurology.org/content/87/7/741.full\#ref-list-1

This article, along with others on similar topics, appears in the following collection(s):

\section{All Cerebrovascular disease/Stroke}

http://n.neurology.org/cgi/collection/all_cerebrovascular_disease_strok e

\section{DWI}

http://n.neurology.org/cgi/collection/dwi

\section{MRI}

http://n.neurology.org/cgi/collection/mri

Other cerebrovascular disease/ Stroke

http://n.neurology.org/cgi/collection/other_cerebrovascular_disease_st roke

Information about reproducing this article in parts (figures,tables) or in its entirety can be found online at:

http://www.neurology.org/about/about_the_journal\#permissions

Information about ordering reprints can be found online:

http://n.neurology.org/subscribers/advertise

Neurology ${ }^{\circledR}$ is the official journal of the American Academy of Neurology. Published continuously since 1951, it is now a weekly with 48 issues per year. Copyright @ 2016 American Academy of Neurology. All rights reserved. Print ISSN: 0028-3878. Online ISSN: 1526-632X.

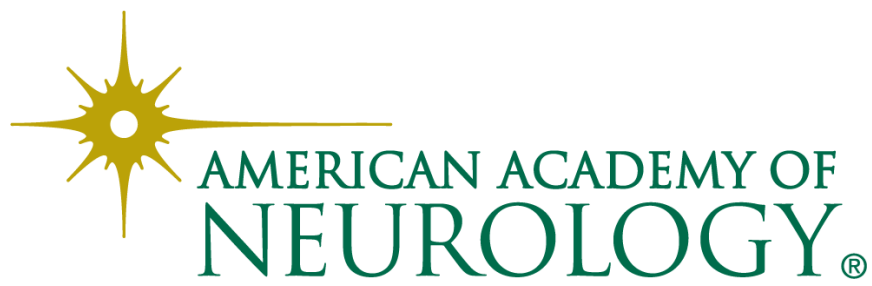

